\title{
硬鋼線の塩酸酸洗イにおける水素吸収について
}

\author{
若松良徳 ${ }^{*} \cdot$ 相良 学 ${ }^{* *} \cdot$ 大西正己 ${ }^{*} \cdot$ 藤渕秀雄 ${ }^{* * *}$
}

\section{Hydrogen Absorption of Hard Steel Wire in Hydrochloric Acid}

Yoshinori WAKAMATSU, Manabu SAGARA, Masami ONISHI and Hideo FUJIBUCHI

The authors measured the amounts of hydrogen absorbed by a hard steel wire $(0.6 \% \mathrm{C})$ with scale during immersion in 5, 10, and $15 \%$ of hydrochloric acid for various times. The rate of hydrogen absorption increased with the increase in descaling ratio and it reached maximum at the descaling time at which the scale was completely removed. The amount of hydrogen absorbed after complete descaling was nearly proportional to the square root of the time after the descaling. The proportion between the two factors decreased with the increase in $\mathrm{HCl}$ concentration. The similar relationship was obtained in the hard steel wire with no scale. It was observed by scanning electron microscopy that $\mathrm{Fe}_{3} \mathrm{C}$ plate crystals protruded out of the steel surface after immersing in $\mathrm{HCl}$. The shapes of $\mathrm{Fe}_{3} \mathrm{C}$ plates tended to be rounded with the increase in $\mathrm{HCl}$ concentration. The protrusion of $\mathrm{Fe}_{3} \mathrm{C}$ indicated that $\mathrm{Fe}_{3} \mathrm{C}$ acted as an effective cathodic site for deposition of hydrogen and the rounded $\mathrm{Fe}_{3} \mathrm{C}$ indicated that $\mathrm{Fe}_{3} \mathrm{C}$ was decomposed into $\mathrm{Fe}$ and $\mathrm{CH}_{4}$ by the attack of deposited hydrogen. The decrease in the amount of absorbed hydrogen with the increase in $\mathrm{HCl}$ concentration would be due to the decrease in effective absorbed hydrogen from the decomposition of $\mathrm{Fe}_{3} \mathrm{C}$.

\section{1. 緒言}

鉄鋼の酸洗イでは, スケールの除去速度が大なること とともに素地の酸食が少ないこと, 同時に水素吸収量の 少ないことが要求される。酸浸セキの条件と水素吸収量 との関係については，多くの研究1) 33 があるが，これら の研究のほとんどはスケールなしの研摩した低炭素鋼に ついて行なわれたもので，スケールの付着した試料はも ちろんのこと高炭素鋼についての研究はほとんどないよ らに思われる。

過去数十年にわたり，鉄鋼の酸洗イは主として硫酸浴 中で行なわれていたが，近年にいたり塩酸浴が用いられ るようになった。本研究では塩酸浴を使用し，スケール の付着したままの熱延硬鋼線のスケール除去過程に打け る水素吸収量を調べた。この場合, 塩酸濃度と水素吸収 量との間には従来軟鋼で報告された結果 ${ }^{1)}$ とは異なる関 係が得られたので，とくにスケールを除去した硬鋼線に ついてを実験を行ない, 硬鋼線のスケールの有無と水素

* 九州工業大学(福岡県北九州市戸畑区仙水町 1-1) The Kyushu Institute of Technology

** 長崎大学工学部（長崎県長崎市文教町 1)

Faculty of Engineering, Nagasaki University

*** 九州工業大学大学院 (福岡県北九州市戸畑区仙水町 1-1) Graduate School, The Kyushu Institute of Technology
吸収量との関係を調べるとともに，比較試料としての軟 鋼線の水素吸収量についても検討した。

\section{2. 実験方法}

実験に供した熱延硬鋼線は黒皮付さの状態で直径 7 $\mathrm{mm}$, 素材の化学組成は C 0.61, Si 0.26, Mn 0.46, P $0.009, \mathrm{~S} 0.002 \%$ あり, この試料を以後, 黒皮硬鋼線 之称する。黒皮除去後の硬鋼線の水素吸収量を調べるに さいし，黒皮硬鋼線をあらかじめ $20^{\circ} \mathrm{C}, 10 \% \mathrm{HCl}$ 中 2 $\mathrm{A} / \mathrm{dm}^{2}$ の電流密度で陰極酸洗イを行ない, その後 $10^{-5}$ $\mathrm{mmHg}$ の真空中で $600^{\circ} \mathrm{C}, 2 \mathrm{~h}$ 加熱することにより,陰極 酸洗イの間に吸収された水素を除去してから実験に供し た。以後,この試料を皮なし硬鋼線と称する。比較試料 としての軟鋼線はスケールのまったく付着しない冷延 6. $5 \mathrm{~mm} \phi$ の溶接心線素材を使用した。冷間加工材では加 工度によって水素吸収量が異なることが報告4),5)されて いるので, この試料についてはあらかじめ $10^{-5} \mathrm{mmHg}$ 真空中 $600^{\circ} \mathrm{C}, 2 \mathrm{~h}$ 加熱することによりヒズミ取りを行 なった。溶接心線素材の化学組成は C 0.12, Si 0.02, Mn 0.55, P 0.009, S $0.019 \%$ であり以後この試料を軟 鋼線と称する。

線材はすべて長サ $50 \mathrm{~mm}$ 一定として，切断面をエメリ 一紙1000番まで研摩した。さらにトリクレン中に浸セキ 脱脂の後, フロンテックスで切断面を被覆して酸漫セキ 

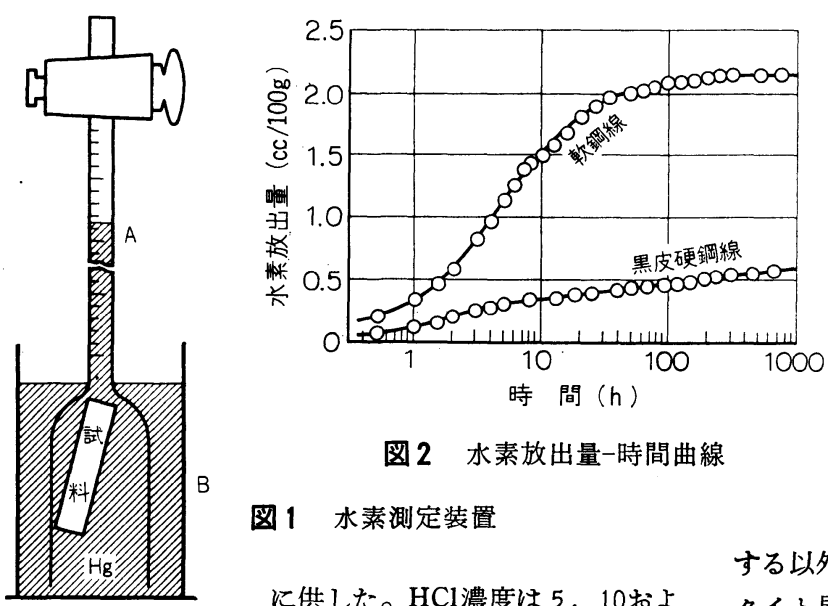

図 2 水素放出量-時間曲線

图 1 水素湘定装置

に供した。 $\mathrm{HCl}$ 濃度は 5,10 お び15\%の 3 種類, 温度は $20 \pm 1{ }^{\circ} \mathrm{C}$ および $40 \pm 1^{\circ} \mathrm{C}$ の 2 種類として, 種々なる時間の浸セキ を行なった。酸浸セキ後ただちに水洗し，フロンテック ス除去乾燥を経て水素吸収量の測定の段取りとなるが, この過程は水素の放散を防止するためできるかぎり時間 を短縮する必要があり，ここでは $2 \mathrm{~min}$ 要した。

水素吸収量の測定は Hudson ${ }^{3), 6)}$ が使用した水銀置換 法を採用した。図 1 は測定装置の概略を示す。Aは水素 ガスの捕集器であり, 水素測定部は約 $3 \mathrm{~mm}$ 間隔で0. 01 $\mathrm{cc}$ ごとに目盛られた $2 \mathrm{~mm} \phi$ の毛細管から成ってい る。捕集器の下部に試料を入れ，図のように水銀を満た した容器 $\mathrm{B}$ 中に置く。捕集器 $\mathrm{A}$ 上部の活栓を利用して, アスピレーターにより水銀を吸い上げた状態で $48 \mathrm{~h}$ 恒温 に保持する。温度は常に $45 \pm 1^{\circ} \mathrm{C}$ 一定とした。試料中の 水素は試料表面で水素ガスとなり, 水銀と置換して捕集 器 $\mathrm{A}$ の上部に蓄積する。水素吸収量はすべて標準状態 $\left(0^{\circ} \mathrm{C}, 1\right.$ 気圧）の体積に換算し，Hudson $\left.{ }^{6}\right)$ にしたが って試料 $100 \mathrm{~g}$ 当たりの水素吸収量とした。

溶接後の溶着金属の水素量測定法を示した JIS Z 3113 によれば，水銀の代わりにグリセリンを使用し，温度は $45^{\circ} \mathrm{C}$ ，時間は $48 \mathrm{~h}$ となっている。したがって本研究に おける水素吸収量の測定条件はJIS に準拠したことにな るが，溶着金属は普通軟鋼であるから，高炭素鋼では45 ${ }^{\circ} \mathrm{C} ， 48 \mathrm{~h}$ の置換で吸収水素の全量が 放出されるかいな かについて疑問が生じる。

図 2 は黒皮硬鋼線打よび比較に用いた軟鋼線を $40^{\circ} \mathrm{C}$, $5 \%$ HCl 中に $30 \mathrm{~min}$ 浸セキの後, $45^{\circ} \mathrm{C}$ で最高 $700 \mathrm{~h}$ 恒温保持したさいの水銀と置换した水素量と保持時間と の関係を示したものである。黑皮硬鋼線は $700 \mathrm{~h}$ 後にお いても一定速度で水素ガスの放出を続けるので, $45^{\circ} \mathrm{C}$, $48 \mathrm{~h}$ では吸収水素の全量が放出されないのは明らかであ る。他方比較試料の軟鋼線は約 $200 \mathrm{~h}$ 後に 放出水素量が 飽和値に達する。鋼中に吸収された水素は格子中に固溶

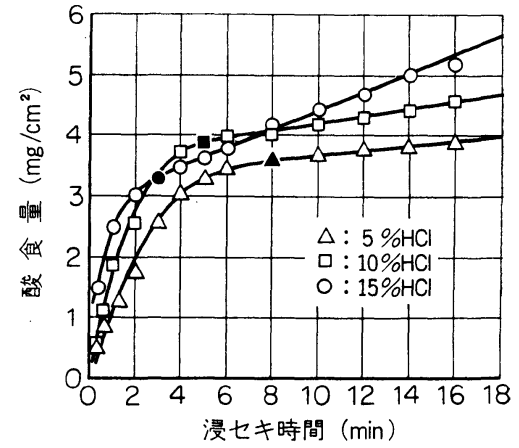

図 3 酸食量-浸セキ時間曲線

する以外にフェライトー不純物界面, フェライトーセメン タイト界面》などの異相境界にも捕そくされる。異相界 面にトラップされた水素の抽出には時間を要し, 低温ほ ど水素は放出されにくい,

Boniszewski ${ }^{9}$ は狯分極により $5.5 \mathrm{ml} / 100 \mathrm{~g}$ の水素を 吸収させた含硫快削鋼の常温における水素放出曲線を測 定し, 100day 後に水素放出量が飽和值に達した時点で 吸収水素の全量が放出されたと述べている。同様に考兄

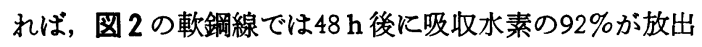
されたことになる。硬鋼線の吸収水素の全量は不明であ るが，含硫快削鋼と同様 100day 後に吸収水素の全量が 放出されるとして，図 2 黒皮硬鋼線の長時間側曲線をと のまま 100day まで外捜した値を吸収水素の全量とすれ ば， $48 \mathrm{~h}$ 後には約70\%の水素が放出されたことになる。

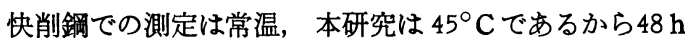
後に打故黒皮硬鋼線の水素放出量は上記 $70 \%$ 以上と推 察されるが，70\%としても水素放出量を水素吸収量とみ なして水素吸収量の多少を比較することは可能である。

もっとも精度の高い水素量測定法は $600 \sim 700^{\circ} \mathrm{C}$ にお ける真空抽出法 ${ }^{10)}$ と考えられるが，測定法がきわめて簡 単なこと,さらに図 1 の装置を多数用いることによって 多くの測定が比較的短時間で可能ということから，45 ${ }^{\circ} \mathrm{C}, 48 \mathrm{~h}$ の水銀置換法を採用することにした。

\section{3. 実験結 果}

\section{3-1 黑皮硬鎡線}

3-1-1 酸食量と付着スケール量

黒皮硬鋼線を $40^{\circ} \mathrm{C} ， 5 ， 10$ おび $15 \% \mathrm{HCl}$ に浸セキ し, 漫セキ時間と酸食量との関係を求めた結果を図 3 に 示す。各濃度に共通して酸食量は浸セキ初期に著しく, その後酸食速度は低下し始め最終的には定常状態に落ち 着く。図 3 の日，ムおよび○印に対応する浸セキ時間で は黒皮が完全に脱落することが認められたので，浸セキ 初期における重量の急減は主としてスケールの脱落に基 づき, 定常状態はスケールが完全に脱落した後での鋼素 


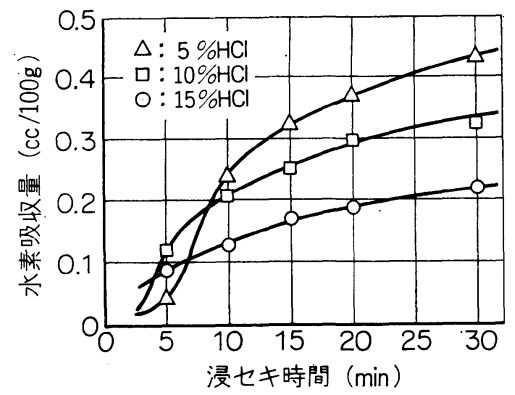

図4 水素吸收曲線

地の溶解に基づくものと考えられる。脱スケール過程に 打ける素地鋼の溶解を無視すると，前記口，ム㧊よび○ に対応する緃軸（酸食量）は近似的にスケール付着量 に，横軸は脱スケール時間に相当する。 $40^{\circ} \mathrm{C}$ における 脱スケール時間は $5 \% \mathrm{HCl}$ で $7 〜 9 \mathrm{~min}, 10 \% \mathrm{HCl}$ では $4 \sim 5 \mathrm{~min}, 15 \% \mathrm{HCl}$ では3〜 $4 \mathrm{~min}$ であった。一定 温度では $\mathrm{HCl}$ 濃度が高くなると脱スケール時間が短く なり，20ㄷ゙も同様であった。

一定温度, 一定 $\mathrm{HCl}$ 濃度において子脱スケール時間 に範囲があるのは硬鋼線の場所によってスケール付着量 が異なるからである。ここで上記脱スケール時間の上限 を選び， $5 \% \mathrm{HCl}$ 中で $9 \mathrm{~min}$ 浸セキ後に扣ける酸食量 を試料68個について測定した結果, 酸食量はほぼ完全な 正規分布を示した。前述のようにここでの酸食量は近似 的にスケール付着量に等しいので, 酸食量から試料単位 面積当たりのスケール量を求めると，平均スケール量は $3.55 \mathrm{mg} / \mathrm{cm}^{2}$ で標準偏差は $0.35 \mathrm{mg} / \mathrm{cm}^{2}$ となる。

\section{3-1-2 水素吸収量}

$40^{\circ} \mathrm{C} ， 5 ， 10$ 抢よび15\% $\mathrm{HCl}$ 中に黒皮硬鋼線を種々 なる時間浸セキしたときの水素吸収量と浸セキ時間との 関係を图 4 亿示す。水素吸収量は浸セキ時間の経過にし たがって増加するが，増加速度は $\mathrm{HCl}$ 濃度によって著 しく異なる。図 4では 4〜9 min を境にして長時間側の 水素吸収量は $5>10>15 \% \mathrm{HCl}$ の順で示されるのに対 し, 短時間側ではほぼ逆の傾向を示す。水素吸収量が逆 転する時間帯の 4 〜 $\min$ は前項で述べたスケールの脱 落時間と関係があることがわかる。な护， $20^{\circ} \mathrm{C}$ 浸セキ の水素吸収量は, $40^{\circ} \mathrm{C}$ に打忷る水素吸収量の経時变化 と同じ挙動を示した。

\section{3-1-3 酸食量と水素吸収量との関係}

スケール付着量が試料によって異なるので，一定の浸 セキ条件下で測定した酸食量はかなり分散する。したが って酸食量と水素吸収量の関係を求めるには多数の試料 について測定を行ない，全体としての傾向から判断する 必要がある。図 5 は $40^{\circ} \mathrm{C} ， 5 ， 10$ および $15 \% \mathrm{HCl}$ 中に お汀る酸食量と水素吸収量との関 引上述の観点に基づ

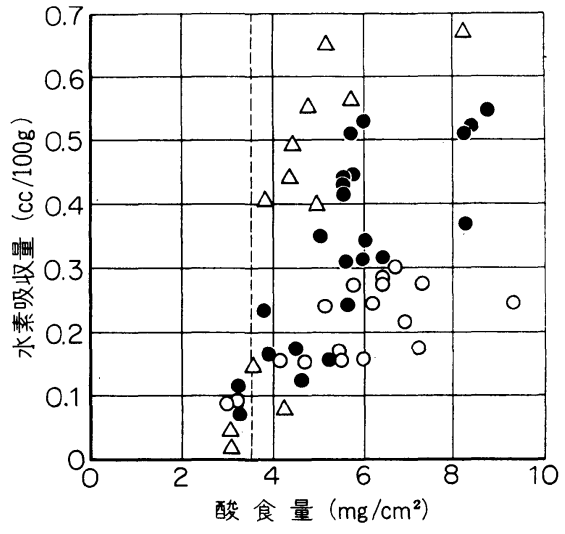

図 5 酸食量と水素吸収量との関係

いて示したものである。 $\triangle$ ○怙よび○印はそれぞれ5， 10扣よび $15 \% \mathrm{HCl}$ の測定値を示し,酸食量が多くなるに

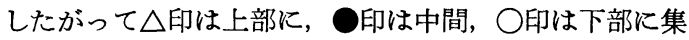
まる傾向が認められる。しかし平均スケール $3.55 \mathrm{mg}$ ／ $\mathrm{cm}^{2}$ を境にして，これより左側では印の位置が逆転する 傾向が認められる。このように硬鋼線の水素吸収量には スケールの有無が大きく影響するので，つぎにスケール のない硬鋼線について実験を行なった。

\section{3一2 皮なし硬鋼線}

図6 $640^{\circ} \mathrm{C} ， 5 ， 10 \%$ 拈よび $15 \mathrm{HCl}$ 中での皮なし 硬鋼線の酸食量と浸セキ時間の関係を示す。いずれの濃 度においても定常状態に達すると, 時間に比例した一定 速度の溶解が進行する。图 7 は皮なし硬鋼線および比較 試料の軟鋼線についての水素吸収量が近似的に浸セキ時 間の平方根に比例することを示して扮り，この関係は軟

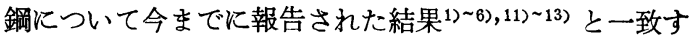
る。

定常状態での酸食量は浸セキ時間に比例し, 水素吸収 量は時間の平方根に比例するので，水素吸収量は定常状 態に打ける酸食量の平方根に比例することになる。图 8 は皮なし硬鋼線の $20^{\circ} \mathrm{C}$ 㧊よび $40^{\circ} \mathrm{C}$ 各種温度の $\mathrm{HCl}$ 浸 セキに拈ける記の関係を示したものであり, 同一浸セ キ条件では水素吸収量 $H$ 之酸食量 $\Delta W$ の平方根との間

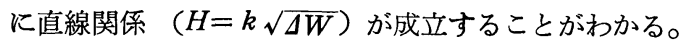
同図より求めた $k$ の值を表 1 亿示す。一定温度に打ける $k$ の值は $\mathrm{HCl}$ 濃度が増加するにしたがって減少する。 つまり，スケールの付着しない硬鋼線では $\mathrm{HCl}$ 濃度が 上昇するにしたがって酸食量は增加し，逆に水素吸收量 は減少するのである。

写真 1 は皮なし硬鋼線を $40^{\circ} \mathrm{C}$ の $\mathrm{HCl}$ に浸セキしたと きの鋼材表面の走査型電子顕微鏡像である。写真 $1 \mathrm{a}$, b 扣よび c は10\% $\mathrm{HCl}$ 中に浸セキしたときの表面像を示 し,アルファベットの順に浸セキ時間が長くなってい 


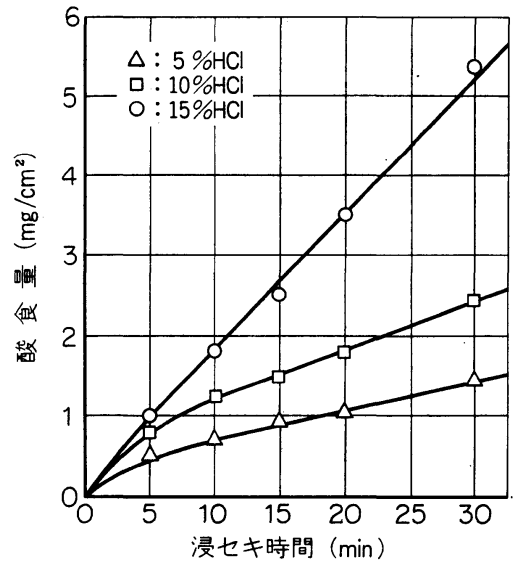

図 6 皮なし硬鋼線の酸食量と浸セキ時間との関係

る。鋼の腐食ではセメンタイトがカソード, フェライト がアノードとなることによってフェライトの優先溶解す ることが知られているが(4),15)，写真 $1 \mathrm{a}, \mathrm{b}$ および c で も同じ現象が認められ，浸セキ時間の経過にしたがって 初析のフェライトおよびパーライト中のフェライトの優 先溶解が目立つようになる。写真 $1 \mathrm{~d}, \mathrm{e}$ 扎よび $\mathrm{f}$ は同 じく $40^{\circ} \mathrm{C}$ の 5,10 物よび $15 \% \mathrm{HCl}$ 中に $30 \mathrm{~min}$ 浸セキ後 の表面像である。腐食が激しくフェライト部分は観察さ れないが， $\mathrm{HCl}$ 濃度が高くなるにしたがってセメンタイ トの溶解も激しくなり, セメンタイトが不鮮明になるこ とがわかる。

\section{4. 考察}

Hudson ${ }^{1)}$ は低炭素鋼 $(0.022 \% \mathrm{C})$ を $38^{\circ} \mathrm{C}$ 各種濃度 の $\mathrm{HCl}$ 中に浸セキし, 酸食量と水素吸収量との関係を 求めた結果, 試料100 g 当たりの水素吸収量 $H(\mathrm{cc})$ と酸 食量 $\left(\mathrm{mg} / \mathrm{cm}^{2}\right)$ との間に $H=8.5 \times \Delta W^{0.37}$ が成立するこ とを示した。一定の $\Delta W$ を得るには，高濃度の $\mathrm{HCl}$ で は短時間低濃度の $\mathrm{HCl}$ では長時間を要するが, $\mathrm{HCl}$ 濃 度あるいは時間之は無関係に一定の $\Delta W$ に対しては定 まった $H$ が得られるのであり，この点が同一の酸食量

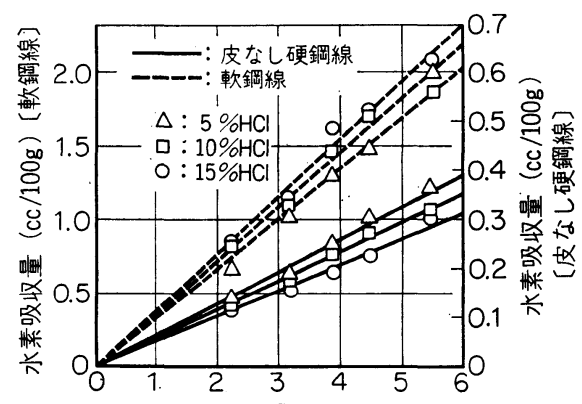

浸セキ時間 $\left(\min ^{1 / 2}\right)$

図 7 水素吸収量と浸セキ時間との関係

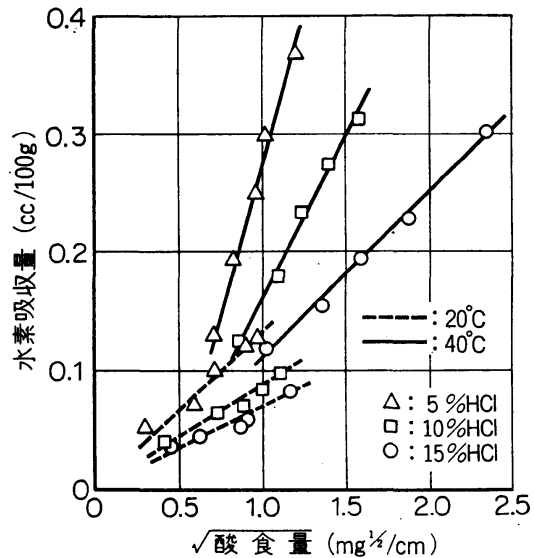

図 8 水素吸収量と酸食量との関係

であっても酸濃度が変化すると水素吸収量も変化する本 研究結果（図 8）と著しく異なる。

皮なし硬鋼線と軟鋼線の水素吸収量を比較した図 7 か ら明らかなよらに，軟鋼線は硬鋼線よりも水素吸収量が 1 ケタ以上大となっている。また，酸浸セキの温度が異 なり，試料寸法も異なるので Hudson の結果と本研究 結果とは直接の比較はできないが，いま酸食量 $\Delta W$ を $1 \mathrm{mg} / \mathrm{cm}^{2}$ とすれば Hudson の結果では水素吸収量 $H$ は $8.5 \mathrm{cc} / 100 \mathrm{~g}$ となる。この值を図 8 に示された酸食量 $1 \mathrm{mg} / \mathrm{cm}^{2}$ 当たりの水素吸収量と比べるとき, $40^{\circ} \mathrm{C}$, $5 \% \mathrm{HCl}$ の值よりも30倍以上大となるので, 鋼中に含有 される炭素含有量が鋼の水素吸収量を左右する重大な因 子であることがわかる。

Abdul Azim ${ }^{16)}$ は種々なる濃度の $\mathrm{HCl}$ 中に打ける鋼 の酸食量を調べた結果，鋼中の炭素含有量が多くなるに したがって酸食量が増加することを示している。鋼中の セメンタイトはフェライトよりる水素過電圧が少ない14 ので, 腐食が水素発生の活性化支配であるかぎりセメン タイト量が多くなるにしたがって腐食量が増大する。高 炭素鋼では水素ガスのほとんどはセメンタイト上で発生 し，低炭素鋼では水素ガスのほとんどはフェライト上で 発生すると考えてさしつかえない。このように，主たる

表 $1 k$ の 值

\begin{tabular}{c|r|c}
\hline \hline 温度 ${ }^{\circ} \mathrm{C}$ & $\mathrm{HCl} \%$ & $k(\mathrm{cc} / 100 \mathrm{~g}) /(\mathrm{mg} 1 / 2 / \mathrm{cm})$ \\
\hline \multirow{3}{*}{20} & 5 & 0.127 \\
& 10 & 0.085 \\
& 15 & 0.069 \\
\hline \multirow{3}{*}{40} & 5 & 0.520 \\
& 10 & 0.265 \\
& 15 & 0.133 \\
\hline
\end{tabular}


水素ガスの発生点が異なることが炭素鋼の水素吸収量を 決定する因子となり，結果に和いて高炭素鋼は水素吸収 量が少なく，逆に低炭素鋼は水素吸収量が多くなる。

硬鋼線に打ける酸食量と水素吸収量との関係は, 図 8 に示したように HCl 濃度が高いと酸食量が多くなるに もかかわらず，逆に水素吸収量が減少することで特筆さ れるべきである。この点について，すべてを無理なく説 明することは困難であるが，下記のような解釈も成立す る。写真 $1 \mathrm{~d}, \mathrm{e}$ および $\mathrm{f}$ に見受けられるように, $\mathrm{HCl}$ 濃度が高くなるにしたがってセメンタイトの溶解が顕著 になる。Staicopolus ${ }^{14)}$ 扣よび Cron ${ }^{17) ~ ら に よ れ は ゙ セ メ ~}$ ンタイトはメタンなどの炭化水素ガスを発生しながら溶 解するといわれている。硬鋼線のセメンタイト上でも炭 化水素ガスが発生するならば， $\mathrm{HCl}$ 濃度が高くなるにし たがって鋼素地の溶解が激しくなり水素発生量子増大す るが，セメンタイトの溶解も激しくなると同時に発生す る炭化水素ガスも増大する。炭化水素ガスと水素ガスと の比率は HCl 濃度が高くなるにしたがって大きくな り, 結果として鋼材に吸収される水素量も減少する可能 性を考学ることができる。

鉄鋼の酸洗イに拈ける脱スケール過程では, スケール がカソード, 鋼素地がアノードとなる。高炭素鋼では脱 スケールによって鋼素地が露出し始めるとやがてカソー ド位置はスケールからセメンタイトに移り変わる。 $\mathrm{HCl}$ 濃度が高いとアノード溶解执よび水素ガスの発生も多い ので，浸セキ時間が比較的短くスケールが支配的なカソ ードとして働く間は $\mathrm{HCl}$ 濃度が大なるほど水素吸収量 は多くなる。脱スケール過程が進行し, 素地が露出する

ことによってセメンタイトが支配的なカソードになると 高炭素鋼特有の性質が表われ， $\mathrm{HCl}$ 濃度が高いほど酸食 量は多くなるが，逆に水素吸収量が減少することにな る。要するにスケールあるいはセメンタイトのどちらか が支配的なカソードになるかによって水素吸収量と酸濃 度との関係が逆転するのであり，これによって水素吸収 量の交錯現象（図4）は説明可能である。

\section{5. 結 言}

$0.61 \% \mathrm{C}$ を含有する黒皮付きの熱延硬鋼線について, 5，10扣よび15\%HClによる酸洗イの間の酸食量と水素 吸収量との関係を調べた。黒皮付き硬鋼線では $\mathrm{HCl}$ 濃 度が高くなるにしたがってスケール脱落時間は短くな り, 酸洗イ時間が短縮できると同時に, 水素吸収量は少 なくなることがわかった。本研究では黒皮の付着してい ない硬鋼線についても検討した結果，硬鋼線では浸セキ $\mathrm{HCl}$ 濃度が高くなるにしたがって酸食量は増大するが, 水素吸収量は減少することが明らかになった。この原因 としては $\mathrm{HCl}$ 濃度が高くなるとメタンを発生しながら セメンタイトの腐食が進行するので, 発生水素の一部が メタンとなることによって，鋼材中に吸収される水素量 が減少することも考光ることが可能である。

$$
\text { (1973-5-16 受理) }
$$

\section{文献}

1) R. M. Hudson, Corrosion, 20, 245 (1964)

2) R. M. Hudson and C.J.Warning, Metal Finishing, October, 58 (1966)

3) R. M. Hudson and C. J. Warning, Corros. Sci., 10, 121 (1970)

4) R. M. Hudson, K. J. Riedy and G. L. Stragand, Corrosion, 16, 115 (1960)

5) R. M. Hudson and G. L. Stragand, Corrosion, 16, 253 (1960)

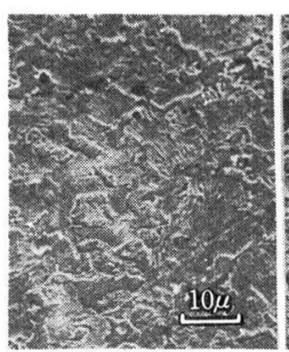

a $10 \% \mathrm{HCl}, 30$ s

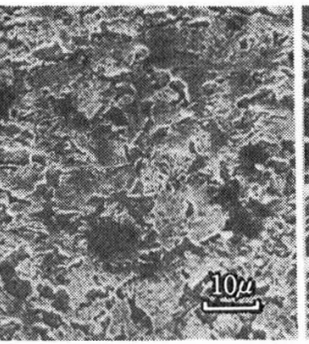

b $10 \% \mathrm{HCl}, 5 \mathrm{~min}$

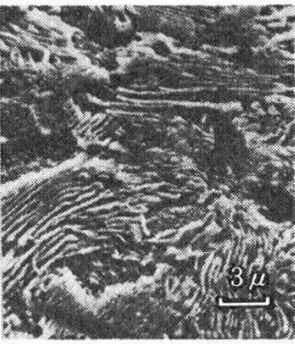

c $10 \% \mathrm{HCl}, 10 \mathrm{~min}$

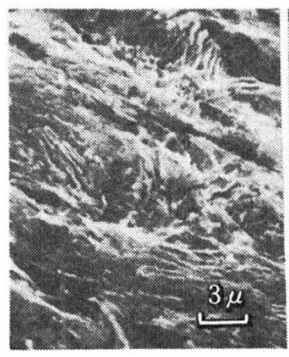

d $5 \% \mathrm{HCl}, 30 \mathrm{~min}$

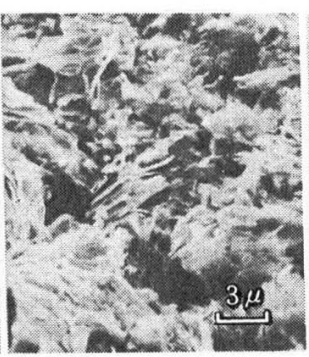

e $10 \% \mathrm{HCl}, 30 \mathrm{~min}$

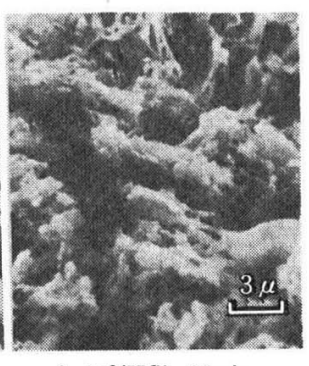

f $15 \% \mathrm{HCl}, 30 \mathrm{~min}$
写真 $1 \mathrm{HCl}$ 浸セキした硬鋼線表面の走査型電子顕微鏡像
6) R. M. Hudson, J. K. Magor and G. L. Stragand, J. Am. Ceram. Soc., 41, 23 (1958)

7) J. F. Newman and L. L. Shreir, J. Iron Steel Inst., 207, 1369 (1969)

8) J. F. Newman and L. L. Shreir, Corros. Sci., 11, 25 (1971)

9) T. Boniszewski and J. Moretone, Brit. Weld. J., 14, 321 (1967)

10) K. Sachs and M. Odgers, J. Iron Steel Inst., 196, 406 (1960)

11) L. S. Darken and R. P. Smith, Corrosion, 5, 1 (1949)

12) R. M. Hudson and G. L. Stragand, Corrosion, 15, 135 (1959)

13) R. M. Hudson and G. L. Stragand, Corros. Sci., 4, 363 (1964)

14) D. N. Staicopolus, J. Electrochem. Soc., 110, 1121 (1963)

15) H. J. Cleary and N. D. Greene, Corros. Sci., 9, 3 (1969)

16) A. A. Abdul Azim and S.H.Sanad, Corros. Sci., 12, 313 (1972)

17) C. J. Cron, J.H. Payer and R. W. Staehle, Corrosion, 27, 1 (1971) 